\title{
Value Addition, Nutritional Parameters and Quality Certifications in Exportable Organic Moringa Produce
}

\author{
R. Saravanakumaran ${ }^{1}$, C. Sekhar ${ }^{2 *}$ and S. Murugesan ${ }^{1}$ \\ ${ }^{1}$ Miracle Tree Life Sciences Private Limited, Alanganallur Main Road, Milakaranai, \\ Madurai - 625 018, India \\ ${ }^{2}$ Department of Agricultural Economics, Tamil Nadu Agricultural University, \\ Coimbatore - 641 003, India \\ *Corresponding author
}

\section{A B S T R A C T}

\section{Ke yw ords \\ Moringa leaf powder, Moringa seed oil, Nutrient composition of Moringa, Amino acid contents of Moringa, Fatty acid profile of Moringa \\ Article Info \\ Accepted: \\ 07 December 2018 Available Online: 10 January 2019}

Moringa Tree found to be the "Poor Man's Physician" as it is capable of curing the human ailments like headache, diarrheal problems, alleviating the human from skin diseases and general vitalize by providing strength to the nerves through the essential amino acids. Such a wonderful plant being the daily diet to human folk in rural pockets has been subjected to chemical analysis to highlight the nutritional, medicinal and other residual and phytosanitary issues to project that the food is something great than any other diet. In this direction, the organically cultivated Moringa leaf powder, Moringa seed oil was subjected to laboratory analysis and the results are presented in this paper. It has addressed the Chemical analysis of Moringa seed oil, Amino Acid contents present in the leaf powder, nutrient composition and the pesticide and heavy metal residues if any available are analyzed and the results are presented in the text. Besides, the need based certification to be obtained for exporting the produce and to get the consumer acceptance is also discussed and presented for better understanding the production and export of value added produce of Moringa.

\section{Introduction}

\section{Introduction to moringa produce manufacturing unit}

"Miracle Tree Life Science" is the firm positioned in Madurai City and this city is the center place of Southern Part of Tamil Nadu. Madurai city is famous for the ruling of King Pandya and it is one of the best tourist place because of the Meenakshi Amman Temple located in the central part of Madurai which was designed and developed in an aesthetic and archeological sense. Besides this Madurai is known for Thirupparankundram where "Lord Murugan" temple is also situated which commands highest inflow of Pilgrims during the festive occasions and commands normal crowd during all other times. In general Madurai city is a known place for siddha and Ayurveda medicines and was prescribed by the traditional healers using indigenous 
medicines and one among the traditional medicine widely used and practiced by the rural folks are Moringa and their products. Miracle Tree Life Sciences is a firm who has developed several products from Moringa and promoted Moringa as the general wellbeing tonic for the humanity through its value added products. Miracle Tree is an ISO 9001-2015 UK certified institution along with HACCP Certification.

Miracle Tree is a partnership Institution established during 2016 and has the following registration numbers for smooth sailing in the production and export front of food products manufactured from Moringa.

Table 1 revealed the details of different types of registration done by the Miracletree Life Science Company for the smooth running of the business. They had obtained the Goods and Services Tax registration; import-export license; APEDA registration; FSSAI registration to ensure food quality; MSME Registration and Organic Certification from the competent authorities.

\section{Miracle of Moringa}

"The Ayurvedic Scripts revealed that the Moringa leaves are capable of preventing 300 diseases that the human normally faces in his routine". Once Moringa was eaten by ancient Indians, Greeks and Egyptians. Moringa oleifera leaves have been used in traditional medicine passed down for centuries in many cultures. More recently, the modern scientific community has begun to validate many of these claims with over 1300 studies and research publications on Moringa. While discussing the health benefits of Moringa, the list is exhaustive and unending. It contains around 20 type of amino acids, 46 antioxidants, 36 anti-inflammatory compounds and more than 90 nutrients which make it one of the best nutritional supplements. It is an excellent source of minerals like iron, calcium and vitamins $\mathrm{A}, \mathrm{B}, \mathrm{B} 1, \mathrm{~B} 2, \mathrm{~B} 3, \mathrm{~B} 6, \mathrm{C}, \mathrm{E}$ as well as macro nutrients, trace minerals and phytonutrients. Besides these, it is a good source of quality protein and dietary fiber. These vivid green leaves are nature's superpower food. It has the power to cure the world from malnutrition. We can use Moringa as part of our daily diet and to aid in our healthy living.

The Unique Processing method practiced by Miracle Tree Life Science firm avoids oxidation and excess heat, yielding a very high 50000 Oxygen Radical Absorption Capacity (ORAC) this protects the valuable nutritional content while delivering an ultra-fine powder with a natural flavor. Specially designed packaging ensures that from harvest of Moringa leaves to the door step, it will maintain its potency and freshness with original green color.

\section{Benefits of nutrients contained in Moringa}

The benefits of all the nutrients contained in dried Miracle Tree Moringa Leaf Powder is furnished as follows for the consumers as well as the benefit of readers.

Enhances the natural defense mechanism of the body

Lowers the Blood Pressure

Protects the stomach lining and assists in the healing of stomach ulcers

Provides nourishment to the eyes and the brain

Promotes metabolism with bio-available ingredients

Promotes the cell structure of the body

Promotes the Natural Serum Cholesterol

Lowers the appearance of Wrinkles and fine lines

Promotes the normal functioning of the liver and the kidney

Aids in healing and beautifies the skin 
Boosts the energy levels in human

Promotes proper digestion

It contains powerful antioxidants

Improved function of Immune system

Promotes healthy circulatory system

Moringa is an Anti-Inflammatory

Gives the feeling of General Wellness and improved Libido

Supports the normal sugar levels in human Reduces pain from menstrual cramps and

Capable of enhancing the face value of the regular Consumer

\section{Products manufactured by the company}

Moringa Products are many and are manufactured through the process of value addition and the Miracle Tree ensures the products are enriched with natural minerals and nutrients which are most essential for the wellness of the human. In the value addition chapter, we have presented a detailed product details and its components. However, here also it is important to add the details of products produced and manufactured by the company. All the products are produced and packed under the trade name of "Miracle Tree". Sources of raw materials for the products are from single herb, the Moringa oleifera and its parts.

\section{Organic moringa leaf powder}

The moringa leaf powder is Chamber dried. The Conversion Ratio is 14:1. From Plugging of leaves to processed leaves and packing as powder within 10 hours. Ultra low temperature drying process which is capable of retaining all nutrients and potency for the benefit of consumers. The pack size produced are 100 grams; 200grams; 500 grams and the bulk package containing $20 \mathrm{~kg}$ powder.

Another variant in the Moringa leaf powder is "Moringa Leaf Powder with Natural Flavor. It is also packed in 100 gram package; 200 grams and 500 grams. The packaged leaf powders are exportable products abroad.

Moringa seed virgin cold pressed oil which is also packed in $100 \mathrm{ml} ; 200 \mathrm{ml}$; $500 \mathrm{ml}$ and 25 litre containers

Moringa dip tea which is packed in 24 dips per pack and the bulk pack containing $20 \mathrm{~kg}$ of Moringa tea bags.

Moringa virgin tablets which is in possession of $600 \mathrm{mg}$ strength per tablet which is easily soluble on consumption. The packing size ranges from 60 to 20000 tablets. The consumer packs are in 60 tablets per bottle; 90 tablets and bulk packing of tablets numbering to 20000 in protected insulated containers.

Moringa capsules - The strength of the capsule is $500 \mathrm{mg}$. The Moringa Capsules are also available in the consumer packs as enshrined in respect of Tablets of Moringa.

Moringa hair serum - This product is for vitalizing the hair follicles which are available in $100 \mathrm{ml}$ packs as lotion and the same is also available in bulk of 5 litre capacity packed in High Density Poly Ethylene (HDPE) containers.

MOGO - The Moringa Energy Bar - It is a Chocolate manufactured using the Moringa leaf extracts and are produced in 20 gram consumer packs. One box contains 10 units. In a master carton, 40 boxes are packed and sent to the consuming units abroad and to the domestic markets.

Moringa wonder mix - This product is produced by the company for the male Erectile Dysfunction exclusively. A power mix packed in 100 gram bottle.

Moringa Happy Days - it is also a product prepared as a Vitalizer for the Couple of middle and aged which is packed in 200 gram HDPE bottles.

Moringa Fully Matured Seeds - Ripened selected fruits from which the seeds were 
extracted and sent to the consuming units as seed itself. This was utilized for further propagation in their soils as well as for value addition

Moringa Flower - Safely dried flowers are packed in different containers and sent to the demanding ends.

Moringa Fruit - Freeze Dried Instant Soup

Moringa Gum

Moringa Smoothie

Moringa Honey

Moringa Crack Cream

Moringa Body Wash Bar - This product is almost paraffin free; Alcohol Free and free from Mineral oils.

Moringa Shower Gel - This product is also free from paraffin, alcohol and mineral oils

\section{Materials and Methods}

The Miracletree Life Sciences Private Limited firm has its own Moringa plantations to the tune of 50 acres which are cultivated following good organic practices and they have the tie up with 12 farmers for getting organic Moringa produce following good organic practices for their regular needs of value addition process. The Moringa leaves were extracted at 45 days of interval from the Organic Farms and are subject to the following steps which are presented in Figure 1. Similarly, the Moringa matured pods were collected from different gardens for extraction of seeds so as to get the Moringa seed oil. The method of processing of Moringa Seed is also presented in Figure 1.

The sample of one hundred gram of Moringa Leaf Powder was sent to the NAWaL Analytical Laboratories for assessing the nutrient contents including minerals and vitamins, amino acid contents, heavy metals, mycotoxins and pesticide residues etc. on 20.12.2017 and the test results were obtained from the Laboratory on January $3^{\text {rd }}, 2018$.
The NAWaL Laboratory is an ISO / IEC 17025-2005 Accredited by NABL and BIS, FSSAI, APEDA and MOEF recognized facility. This laboratory is based at Hosur, Tamil Nadu.

Similarly, one hundred $\mathrm{ml}$ of Moringa Seed Oil were also sent to the NEOGEN Food and Animal Security (India) Private Limited which is positioned at Poonithura post, Cochin for Chemical Analysis of Moringa Seed Oil on $4^{\text {th }}$ August 2017 and the firm was in receipt of the test results 14th August 2017. The tests conducted were chemical analysis of Moringa seed oil for assessing moisture content, Iodine value, peroxide value, saponification value, density and viscosity etc. besides assessing the Fatty Acid Profile and heavy metals. These results were analyzed and the test results are discussed in various sections of Results and Discussion.

\section{Results and Discussion}

\section{Nutrient composition of moringa produce}

The Miracletree Life Science is producing around 18 products from Moringa to its credit and the products are certified by different organizations. Before discussing the details of certification the produce has to undergo, it is important to assess the nutrient composition of Moringa produce. Let us discuss the nutrient composition in the Organic Moringa Leaf Powder. The conversion ratio of Moringa leaf powder is $14: 1$. That is 14 unit of fresh leaves are required to produce one unit of dried Moringa leaf powder. The samples of the leaf powder were given to the NAWAL Analytical Laboratories by the Miracle Tree Life Science during the month of January 2018 and the tested samples and their nutrient contents are revealed in the Table 2 .

Table 2 revealed the details of chemical parameters, minerals and vitamins. In respect 
of calories, Moringa leaf powder is capable of providing $233.64 \mathrm{Kcal} / 100$ Grams of leaf powder. Protein, Total Carbohydrate and Poly Phenols are almost equal in quantity which is ranging between 21 to 23 grams per 100 grams of Moringa leaf powder. Total fat is also available in the Moringa leaf powder which is also arrived at 5.40 grams per one hundred grams of leaf powder. Sugar content is also available but it is lesser than 0.50 grams per 100 grams of leaf powder. It revealed that the Moringa leaf powder is capable of keeping all the essential calorific elements and hence consumption of Moringa keeps the human always energetic. Followed by chemical parameters, Minerals play an important role in building the human body to feel hale and healthy.

Among the minerals, potassium is available to the highest quantity per one hundred gram of Moringa leaf powder which is arrived at 3630 $\mathrm{mg}$ followed by Calcium is available to the tune of $1619 \mathrm{mg}$ per hundred gram of leaf powder. Potassium is a very significant body mineral, important to both cellular and electrical function. Magnesium helps maintain the potassium in the cells, but the sodium and potassium balance is as finely tuned as those of calcium and phosphorus or calcium and magnesium. In a study conducted by Amabye during the year 2015, Moringa leaf powder exhibited moisture levels varying from 3.06 per cent to 3.34 per cent. Fiber from 7.29 per cent to 9.46 per cent, ashes from 10.71 per cent to 11.18 per cent, crude protein from 10.74 per cent to 11.48 per cent and carbohydrates from 54.61 per cent to 57.61 per cent. The predominant mineral elements in the leaf powder were $\mathrm{Ca}$ (2016.50 to $2620 \mathrm{mg}$ / 100 gram; Potassium (K) available to the level of 1817 to $1845 \mathrm{mg}$ per one hundred gram of leaf powder and Magnesium $(\mathrm{Mg})$ available to the tune of 322.50 to $340.60 \mathrm{mg}$ per one hundred gram of Moringa leaf powder.
Vitamin - A is present in the Moringa leaf powder to the tune of $916 \mu \mathrm{g} / 100 \mathrm{Grams}$ of leaf powder. Vitamin $-\mathrm{E}$ is predominant in Moringa leaf powder as per the test results of NAWAL laboratories and hence it is acting as a basic ingredient in preparation of Vitalizer medicines. Vitamin $\mathrm{E}$ is an antioxidant that occurs naturally in Moringa leaf powder and also present in nuts, seeds, and leafy green vegetables. Vitamin $\mathrm{E}$ is a fat-soluble vitamin important for many processes in the body. Vitamin $\mathrm{E}$ is used to treat or prevent vitamin $\mathrm{E}$ deficiency. People with certain diseases may need extra vitamin $E$ based on the prescriptions of the physicians. People above the age of 60 can take one tablet of Vitamin $\mathrm{E}$ which is available in Moringa leaf powder.

Vitamin $-\mathrm{C}$ is available to the lesser quantity when compared to the Vitamin - E. Vitamin $\mathrm{C}$ is available to the tune of $9.16 \mathrm{mg}$ per hundred gram of Moringa leaf powder. Vitamin C, also known as ascorbic acid, which is necessary for the growth, development and repair of all body tissues. It is involved in many body functions, including formation of collagen, absorption of iron, the immune system, wound healing, and the maintenance of cartilage, bones, and teeth and also develops resistance in the human body.

\section{Pesticide and mycotoxin residues present in the sample of moringa leaf powder}

We had a detailed discussion on the availability of nutrients like minerals, vitamins and chemical parameters in the Moringa leaf powder which are produced in an organic way. Here it is important to analyze the pesticide and heavy metals residue availability so as to send the same to the consumers abroad. These details are analyzed and the results are presented in Table 3.

The Moringa leaf powder samples were given to the NAWaL Analytical Laboratories 
located in New Sidco Industrial Estate, Sri Nagar, Hosur which is an accredited lab by Food Safety and Security Authority of India (FSSAI), Agricultural Processed Food Products Export Development Authority (APEDA), National Accreditation Board for Testing and Calibration Laboratories (NABL), AGMARK and Ministry of Environment and Forests, Government of India. The Head of NAWaL Analytical Laboratories Mr.D. Balakrishnan gave the report of the analyzed sample Moringa leaf powder on 3rd January 2018.

The quantity of sample sent to the NAWaL Analytical Laboratories are 3 X 200 grams packets of Moringa Leaf Powder which was sent for analysis on $18^{\text {th }}$ December 2017. They have examined not only for the presence of calories, minerals, vitamins but also the mycotoxins, pesticide residues and the presence of heavy metals.

The test reports revealed that the Mycotoxins and the Pesticide Residues are in Below the Detectable Limit (BDL). The Mycotoxins are below the detectable limit of one $\mu \mathrm{g} / \mathrm{kg}$ and the naturally occurring substances like Agaric Acid is also at below the detectable limit of 10 mg per $\mathrm{kg}$ of the sample. The Saffrole and Hydrocyanic Acid is at the below detectable limit of one mg per $\mathrm{kg}$ of the sample.

The Pesticide residues delineated in the Table 3 are below the detectable limit of $0.01 \mathrm{mg}$ per $\mathrm{kg}$ of the Moringa leaf powder sample has outlined that the organically produced Moringa leaf powder by the Miracletree Lifescience company is free from Mycotoxin and other Pesticide residues which are considered to be harmful are not present in the sample and hence the product becomes qualitative one for export. Besides these, one has to document the presence or absence level of heavy metals also in the sample because it is being promoted as number one Moringa produce for human consumption abroad and hence the presence of heavy metals is also analyzed and the results are presented in Table 4.

\section{Amino acids in moringa leaf powder}

The organically produced Moringa Leaf Powder was also subjected to the tests of presence or absence of amino acids and heavy metals. The rests results were presented in Table 4. Among the amino acids, the content of L-Arginine is found to be maximum in respect of Moringa leaf powder. In the human body, the amino acid "Arginine" changes into Nitric Oxide. The Nitric Oxide is a powerful neurotransmitter that helps the blood vessels relax and also improves circulation of blood. Since "Arginine" amino acid may help the arteries relax and improve the blood flow through the nervous system, it may also help the erectile dysfunction in men. Hence arginine assumes greater importance in maintaining the potency of men irrespective of age groups. The amino acid "Arginine" is present in the sample to the tune of $1684 \mathrm{mg}$ per one hundred gram of leaf powder. So regular intake of arginine keeps the man alive in all respects.

Arginine is also called as L-arginine, is involved in a number of different functions in the human body. They include wound healing action; helping the kidneys remove waste products from the human system and maintaining the immune system and hormone function besides relax the arteries by dialecting the thickness of the blood so as to flow easily and hence L-arginine assumes greater importance to the human which is available from naturally available Moringa Leaf Powder (Table 4).

Valine is another amino acid present in the Moringa Leaf Powder to the tune of $559 \mathrm{mg}$ per hundred gram of leaf powder. Valine 
greatly improves the regulation of the immune system of the human, but probably the greatest benefits of Valine are experienced by athletes performing long distance sports and body building, because this Valine amino acid is important for the muscle tissue recovery and for the muscle metabolism (Table 4).

Another amino acid which is greatly available in Moringa Leaf Powder is Phenylalanine. It is also pronounced as DL- Phenylalanine. It is available in Moringa leaf powder to the tune of $453 \mathrm{mg}$ per hundred gram of leaf powder. "Phenylalanine is found naturally in the breast milk of mother or the mammals of animals. It is used in the manufacture of food and drink products and sold as a nutritional supplement for its reputed analgesic and antidepressant effects. As an essential amino acid, Phenylalanine is not synthesized in humans and other animals who must ingest Phenylalanine containing proteins. Good sources of Phenylalanine are Eggs, Chicken, Liver, Beef, Milk and Soybeans.

Other amino acids which are considerably available in larger quantities are DL.-norLeucine, DL - Serine, DL-2-Amino-n-Butyric Acid and their respective quantities are accounted to be $374 \mathrm{mg}, 331 \mathrm{mg}$ and $308 \mathrm{mg}$ per one hundred gram of Moringa Leaf Powder. On examining the amino acid content available in the Moringa Leaf Powder, one can say that the Moringa is the divine medicinal plant for establishing good health of human.

Besides amino acids, the sample has also been exposed for analysis to identify the presence of heavy metals if any in the samples of Moringa leaf powder. On examining, the test results revealed that the Lead, Cadmium, Arsenic and Mercury are available Below the Detectable Limit of one milli gram per one hundred gram of the sample indicates the purity of Moringa Leaf Powder and hence one can consume the powder without any fear over the health issues.

\section{The chemical analysis of moringa seed oil}

Moringa oil is extracted from the seeds of Moringa oleifera tree which is grown widely in the tropical environment. These are extremely rich in Phytonutrients and can make a great impact on your overall health. Moringa oil is exceptionally famous for the numerous benefits that it offers. It is really famous in the skin and beauty care industry.

The benefits of Moringa seed oil are found to have anti-aging characteristics. It helps removes wrinkles and prevents the sagging of facial skin as well. It comes filled with antioxidants that slow the aging process down and help curb the activity of free radicals.

Besides anti-aging character, it also helps skin fatigue and its oil secretion. It is really great in counterfeiting the ill effects of pollution on your skin. It's a great skin purifier, making it glow naturally and develops fairness. In this context one has to assess the chemical constituents present in the Moringa seed oil and hence the $100 \mathrm{ml}$ sample has been provided to the NEOGEN food and animal security (India) Private Limited located in Cochin and the test results were received by the company and the details of results are presented in Table 5.

The Chemical Analysis of Moringa Seed Oil focusing the moisture content, melting point, iodine value, saponification value, peroxide value, density of the oil at 20 degree Celsius, viscosity and the phosphorous contents were tested and the test results are outlined in Table 5. The saponification value of Moringa seed oil is arrived at 184.89 units. Saponification value is the number. It represents the number of milligrams of Potassium hydroxide required to saponify one gram of fat under the conditions specified. It is a measure of the average molecular weight or chain length of all the fatty acids present. 
The Viscosity of Moringa seed oil was measured through U-Tube Viscometer which are the devices are also known as glass capillary viscometers or Ostwald viscometers named after Wilheim Ostwald which consists of a U-shaped glass tube held vertically in a controlled temperature bath. Such viscometers can be classified as direct flow or reverse flow. Reverse flow viscometers have the reservoir above the markings and direct flow is those with the reservoir below the markings. Such classifications exist so that the level can be determined even when opaque or staining liquids are measured, otherwise the liquid will cover the markings and make it impossible to gauge the time the level passes the mark. Such a way the viscosity was measured in respect of Moringa seed oil and are arrived at 91.47 centistokes (cSt). In United States Usage, stoke is sometimes used as the singular form. The peroxide value of Moringa Seed oil is arrived at 0.61 milli equivalent per $\mathrm{kg}$. The Peroxide value is defined as the amount of peroxide oxygen per one kilogram of fat or oil. Traditionally it was expressed in units of mill equivalents although if we are using SI units, then the appropriate option would be in Mill moles per kilogram of seed oil.

The Melting Point of Moringa seed oil is arrived at 8.10 degree Celsius. The oil is highly unsaturated, containing high percentages of tri-unsaturated which is accounted for 43.7 degree Celsius and the diunsaturates (36.70 per cent). It is liquid at room temperature with a low melting point. It is pale yellow in color with yellow and red indices of $6.1 \mathrm{Y}+0.7 \mathrm{R}$.

The Iodine value is arrived at 67.21 in respect of Moringa seed oil. In some literature, the range of iodine value present in the Moringa seeds were arrived at $80-85$ per $100 \mathrm{ml}$ of oil. The low iodine value of this oil makes it suitable for biodiesel production since high iodine value leads to the formation of deposits on engines and problem during storage of the fuel and will not permit easy flow. Iodine value of the Moringa oil decreases with increase in the heating time. So optimal heating is required. In the sample given for testing, the iodine value is around 67 and hence one could infer that the iodine value of Moringa seed oil extracted under organic condition is more suitable for biodiesel production too.

\section{Profile of fatty acids in moringa seed oil}

The next important product from Moringa is Moringa Seed Oil which has to be tested for its fatty acid contents which are also considered to be essential and hence these details were also analyzed in the laboratories and the test results of Moringa Seed oil is presented in Table 6.

The fatty acids present in the Moringa Seed oil were Oleic acid, Palmitic acid, Behenic acid, stearic acid, Arachidic acid and Gadoleic acid etc are available in considerable units. Among these, Oleic acid content found to be the highest in Moringa seed oil. The results revealed that the oleic acid present in the Moringa seed oil is found to be to the tune of 68.36 per cent. In some of the studies, the Oleic acid presence is quantified to the tune of 76 per cent (Researchgate.net). The chemical composition of the oil recommends its use in the pharmaceutical preparations especially for skin related treatments in human. The presence of Palmitic acid is arrived at 6.55 per cent. Whereas, the Stearic acid and the Behenic acid presence were respectively estimated as 5.99 and 6.00 per cent. The Moringa seed oil was also subjected to the analysis for detecting the presence of heavy metals if any and hence these results are presented in Table 7.

The heavy metals like Copper and Iron were 
unable to be detected in the sample estimation. The limit of quantification is arrived at 0.05 $\mathrm{mg}$ per $\mathrm{kg}$ of seed oil. The same scenario was also present in respect of iron. The undetectable level of heavy metals in the Moringa seed oil might be due to the growing conditions of Moringa. Since the manufacturer is directly practicing and advocating the organic way of establishing Moringa, the heavy metal presence could not be detected and hence it is highly suitable for human consumption.

With a high content of antioxidants and skin rejuvenating properties associated with Moringa seed oil, the skin becomes good in color and add brightness by infusing the skin easily. It naturally moisturizes dry skin without leaving the greasy oily feeling that other oils do. It's great for conditioning hair and scalp because of the numerous essential vitamins and minerals it contains.

Moringa oil is quickly absorbed into the skin and is perfect for dry and flaking skin and is a popular ingredient in blended massage oils. It is pleasant to touch, warms well, not sticky and combines well with other oils and fragrances. As a result of its tremendous antimicrobial properties, it acts as a deep, gentle cleansing agent for hair, scalp and skin. It is one of the best cooking oils in the world and great therapeutic massage oil. The uses and benefits of Moringa oil are simply beyond measure.

Food safety and security issues with moringa

Because of preference of Moringa produce for its wide applications not only in domestic market but also in markets abroad and the export possibility is gaining over the years. In this respect, ensuring food quality and safety becomes much more important and hence production of Moringa through organic way of approach by ensuring Good Agricultural
Practices and Good Manufacturing Practices will definitely impart the quality output. Before it reaches the hands of the consumers, the manufacturer has to ensure different quality related certification from different agencies or organizations and hence these details are analyzed and the results are outlined in Table 8.

Food quality and safety certification included are Good Manufacturing Practices, HALAL certification, HACCP certification and International Standards Organization (ISO) 9001:2015. These four certificates were awarded to the Chief Executive Officer of Miracletree Life Sciences private limited, Madurai. The certificate of GMP was obtained from International Accreditation Bureau based at London. The validity of the certificate issued is for three years and the validity becomes ceased by September 2019.

HALAL certification was also obtained because of the origin of the produce from organic nature. This certificate was issued to the manufacturing firm during September 2016 and the validity is upto September 2019. After examining the product of organic nature, the certificate was issued to the company.

HACCP certification was issued to the company by $\mathrm{M} / \mathrm{S}$ Ingrain Standards Assessment LLP located at Madurai which has its headquarter with United Kingdom and does the services to the organic producers of products. This certificate becomes much important if the company intends to export the produce abroad.

ISO 9001:2015 certification was issued to the company because of meeting the international standards in export of food produce and are within the expected standards of different nations and hence the certificate issued to the company during the month of June 2018 and the validity of the certificate extended upto the month of June 2021. 
From that one could infer that the product produced from Moringa are meeting the different quality parameters fixed by the importing nations and hence the certificates were issued.

\section{Health benefits of moringa}

The University of Aarhus in Denmark has carried out several experiments in this regard. Under Laboratory Conditions, a "youth preserving effect" of Zeatin on human connective tissue cells. At the University of Nanjing in China, a correlation between Zeatin and the effects of UVB-radiation on the skin was discovered.

The Anti-Aging effect of Zeatin that was discovered in the Danish Study was mostly based on the following observations.

Zeatin prevented the growth of cells Residue in the cells (intra cellular debris) was reduced
Cells showed an improved ability to respond to oxidative stress.

What is important is that all these positive effects of Zeatin occur without having any negative effects on cell-division processes. To conclude the study states that Zeatin has no negative effects of any kind. This positive characteristic of Zeatin has seen it become increasingly popular, in particular to the cosmetics industry.

Zeatin belongs to the group of Cytokinines and is found in plants. Zeatin is a so called Phytohormone. A look at the Greek origin of the word (Zytoes means cell; kinesis means movement) gives us a clue that Zeatin influences the growth and development of plants through its effect on cell-division processes. When compared to other plants, Moringa contains a large amount of Zeatin. Moringa plants can grow several feet in a short time frame. This ability for quick and substantial growth possibilities are mainly related to the effects of Zeatin present in Moringa.

Table.1 Details of registration made by miracle tree life science limited

\begin{tabular}{|c|l|l|}
\hline Sl. No & \multicolumn{1}{|c|}{ Details of Registration } & \multicolumn{1}{|c|}{ Registration Numbers } \\
\hline $\mathbf{0 1}$ & Name of the Company & $\begin{array}{l}\text { Miracle Tree Life Sciences Private } \\
\text { Limited, Milakaranai, Madurai }-625 \\
018\end{array}$ \\
\hline $\mathbf{0 2}$ & $\begin{array}{l}\text { Company Goods and Services Tax } \\
\text { Number (GST) }\end{array}$ & 33ABBFM9432C1ZM \\
\hline $\mathbf{0 3}$ & Import - Export License Number & 3516904429 \\
\hline $\mathbf{0 4}$ & APEDA Registration Number & 181992 \\
\hline $\mathbf{0 5}$ & FSSAI Registration Number & 12418012002283 \\
\hline $\mathbf{0 6}$ & MSME Registration Number & TN12B0006231 \\
\hline
\end{tabular}


Table.2 Nutrient composition in organic moringa leaf powder

\begin{tabular}{|c|c|c|c|}
\hline Sl. No & Particulars of Nutrients / Minerals & Units & Test Results \\
\hline \multicolumn{4}{|c|}{ Chemical Parameters } \\
\hline 01 & Calories & Kcal/100 Grams & 233.64 \\
\hline 02 & Total Carbohydrate & Gram/100 Grams & 22.61 \\
\hline 03 & Total Fat & Gram/100 Grams & 05.40 \\
\hline 04 & Dietary Fibre & Gram/100 Grams & 02.56 \\
\hline 05 & Protein & Gram/100 Grams & 23.65 \\
\hline 06 & Peroxide Value & Gram/100 Grams & 00.00 \\
\hline 07 & Poly Phenol & Gram/100 Grams & 21.78 \\
\hline 08 & Sugar & Gram/100 Grams & $<00.50$ \\
\hline \multicolumn{4}{|c|}{ Minerals } \\
\hline 09 & Calcium $(\mathrm{Ca})$ & mg / 100 Grams & 1618.86 \\
\hline 10 & Magnesium $(\mathrm{Mg})$ & $\mathrm{mg} / 100$ Grams & 377.65 \\
\hline 11 & Potassium & $\mathrm{mg} / 100$ Grams & 3629.70 \\
\hline 12 & Sodium $(\mathrm{Na})$ & $\mathrm{mg} / 100$ Grams & 158.29 \\
\hline 13 & Iron $(\mathrm{Fe})$ & $\mathrm{mg} / 100$ Grams & 11.29 \\
\hline 14 & Copper $(\mathrm{Cu})$ & $\mathrm{mg} / 100$ Grams & 01.27 \\
\hline 15 & Zinc (Zn) & $\mathrm{mg} / 100$ Grams & 02.11 \\
\hline \multicolumn{4}{|c|}{ Vitamins } \\
\hline 16 & Vitamin - A & $\mu \mathrm{g} / 100$ Grams & 916.03 \\
\hline 17 & Vitamin - C & $\mathrm{mg} / 100$ Grams & 09.16 \\
\hline 18 & Vitamin - E & $\mathrm{mg} / 100$ Grams & 43.96 \\
\hline 19 & Vitamin - K & $\mathrm{mg} / 100$ Grams & BDL (DL 0.05) \\
\hline 20 & Vitamin - B1 - Thiamin & $\mathrm{mg} / 100$ Grams & 00.83 \\
\hline 21 & Vitamin - B2 - Riboflavin & $\mathrm{mg} / 100$ Grams & 05.30 \\
\hline 22 & Vitamin - B6 & $\mathrm{mg} / 100$ Grams & 00.80 \\
\hline
\end{tabular}

Table.3 Mycotoxin and pesticide residues present in the sample moringa leaf powder

\begin{tabular}{|c|l|c|c|}
\hline Sl. No & \multicolumn{1}{|c|}{$\begin{array}{c}\text { Particulars of Nutrients / } \\
\text { Minerals }\end{array}$} & Units & Test Results \\
\hline \multicolumn{3}{|c|}{ Mycotoxins } \\
\hline $\mathbf{0 1}$ & Aflatoxin B1 & $\mu \mathrm{g} / \mathrm{kg}$ & $\mathrm{BDL}[\mathrm{DL}-1.0]$ \\
\hline $\mathbf{0 2}$ & Aflatoxin B2 & $\mu \mathrm{g} / \mathrm{kg}$ & $\mathrm{BDL}[\mathrm{DL}-1.0]$ \\
\hline $\mathbf{0 3}$ & Aflatoxin G1 & $\mu \mathrm{g} / \mathrm{kg}$ & $\mathrm{BDL}[\mathrm{DL}-1.0]$ \\
\hline $\mathbf{0 4}$ & Aflatoxin G2 & $\mu \mathrm{g} / \mathrm{kg}$ & $\mathrm{BDL}[\mathrm{DL}-1.0]$ \\
\hline $\mathbf{0 5}$ & Zearlenone Natually Occurring Toxin Substances & $\mathrm{ND}[\mathrm{DL}-1.0]$ \\
\hline \multicolumn{4}{|c|}{$\mathrm{Mg} / \mathrm{kg}$} \\
\hline $\mathbf{0 7}$ & Agaric Acid & $\mathrm{Mg} / \mathrm{kg}$ & $\mathrm{BDL}[\mathrm{DL}-10.0]$ \\
\hline $\mathbf{0 8}$ & Hypericine & $\mathrm{Mg} / \mathrm{kg}$ & BDL[DL -0.250$]$ \\
\hline $\mathbf{0 9}$ & Saffrole & $\mathrm{Mg} / \mathrm{kg}$ & BDL[DL -1.0$]$ \\
\hline
\end{tabular}




\begin{tabular}{|c|c|c|c|}
\hline 10 & Hydrocyanic Acid (HCN) & $\mathrm{Mg} / \mathrm{kg}$ & $\mathrm{BDL}[\mathrm{DL}-1.0]$ \\
\hline \multicolumn{4}{|c|}{ Pesticide Residues } \\
\hline 11 & Aldrin & $\mathrm{Mg} / \mathrm{kg}$ & $\mathrm{BDL}[\mathrm{DL}-0.01]$ \\
\hline 12 & Dieldrin & $\mathrm{Mg} / \mathrm{kg}$ & $\mathrm{BDL}[\mathrm{DL}-0.01]$ \\
\hline 13 & Carbaryl & $\mathrm{Mg} / \mathrm{kg}$ & $\mathrm{BDL}[\mathrm{DL}-0.01]$ \\
\hline 14 & Diazinon & $\mathrm{Mg} / \mathrm{kg}$ & $\mathrm{BDL}[\mathrm{DL}-0.01]$ \\
\hline 15 & Dichlorvos & $\mathrm{Mg} / \mathrm{kg}$ & $\mathrm{BDL}[\mathrm{DL}-0.01]$ \\
\hline 16 & Fenitrothion & $\mathrm{Mg} / \mathrm{kg}$ & $\mathrm{BDL}[\mathrm{DL}-0.01]$ \\
\hline 17 & Heptachlor & $\mathrm{Mg} / \mathrm{kg}$ & $\mathrm{BDL}[\mathrm{DL}-0.01]$ \\
\hline 18 & Beta isomer & $\mathrm{Mg} / \mathrm{kg}$ & $\mathrm{BDL}[\mathrm{DL}-0.01]$ \\
\hline 19 & Gamma isomer & $\mathrm{Mg} / \mathrm{kg}$ & $\mathrm{BDL}[\mathrm{DL}-0.01]$ \\
\hline 20 & Malathion & $\mathrm{Mg} / \mathrm{kg}$ & $\mathrm{BDL}[\mathrm{DL}-0.01]$ \\
\hline 21 & Phosphamidon & $\mathrm{Mg} / \mathrm{kg}$ & $\mathrm{BDL}[\mathrm{DL}-0.01]$ \\
\hline 22 & Chlorfenvinphos & $\mathrm{Mg} / \mathrm{kg}$ & $\mathrm{BDL}[\mathrm{DL}-0.01]$ \\
\hline 23 & Chlorpyrifos & $\mathrm{Mg} / \mathrm{kg}$ & $\mathrm{BDL}[\mathrm{DL}-0.01]$ \\
\hline 24 & $2,4 \mathrm{D}$ & $\mathrm{Mg} / \mathrm{kg}$ & $\mathrm{BDL}[\mathrm{DL}-0.01]$ \\
\hline 25 & Ethion & $\mathrm{Mg} / \mathrm{kg}$ & $\mathrm{BDL}[\mathrm{DL}-0.01]$ \\
\hline 26 & Monocrotophos & $\mathrm{Mg} / \mathrm{kg}$ & $\mathrm{BDL}[\mathrm{DL}-0.01]$ \\
\hline 27 & Carbendazim & $\mathrm{Mg} / \mathrm{kg}$ & $\mathrm{BDL}[\mathrm{DL}-0.01]$ \\
\hline 28 & Benomyl & $\mathrm{Mg} / \mathrm{kg}$ & $\mathrm{BDL}[\mathrm{DL}-0.01]$ \\
\hline 29 & Carbofuran & $\mathrm{Mg} / \mathrm{kg}$ & $\mathrm{BDL}[\mathrm{DL}-0.01]$ \\
\hline 30 & Fenthion & $\mathrm{Mg} / \mathrm{kg}$ & $\mathrm{BDL}[\mathrm{DL}-0.01]$ \\
\hline 31 & Phenthoate & $\mathrm{Mg} / \mathrm{kg}$ & $\mathrm{BDL}[\mathrm{DL}-0.01]$ \\
\hline 32 & Phorate & $\mathrm{Mg} / \mathrm{kg}$ & $\mathrm{BDL}[\mathrm{DL}-0.01]$ \\
\hline 33 & Butachlor & $\mathrm{Mg} / \mathrm{kg}$ & $\mathrm{BDL}[\mathrm{DL}-0.01]$ \\
\hline 34 & Fluvalinate & $\mathrm{Mg} / \mathrm{kg}$ & $\mathrm{BDL}[\mathrm{DL}-0.01]$ \\
\hline 35 & Metasulfuran Methyl & $\mathrm{Mg} / \mathrm{kg}$ & $\mathrm{BDL}[\mathrm{DL}-0.01]$ \\
\hline 36 & Anilophos & $\mathrm{Mg} / \mathrm{kg}$ & $\mathrm{BDL}[\mathrm{DL}-0.01]$ \\
\hline 37 & Cymoxanil & $\mathrm{Mg} / \mathrm{kg}$ & $\mathrm{BDL}[\mathrm{DL}-0.01]$ \\
\hline 38 & DDT & $\mathrm{Mg} / \mathrm{kg}$ & $\mathrm{BDL}[\mathrm{DL}-0.01]$ \\
\hline 39 & Heptachlorine & $\mathrm{Mg} / \mathrm{kg}$ & BDL[DL - 0.01] \\
\hline 40 & Hexachloran Gamma Isomer & $\mathrm{Mg} / \mathrm{kg}$ & $\mathrm{BDL}[\mathrm{DL}-0.01]$ \\
\hline \multicolumn{4}{|c|}{ Organo Phosphors Compounds } \\
\hline 41 & Phosphors Compounds & $\mathrm{Mg} / \mathrm{kg}$ & $\mathrm{BDL}[\mathrm{DL}-0.01]$ \\
\hline \multicolumn{4}{|c|}{ Other Contaminants } \\
\hline 42 & Melamine & $\mathrm{Mg} / \mathrm{kg}$ & $\mathrm{BDL}[\mathrm{DL}-0.001]$ \\
\hline \multicolumn{4}{|c|}{ Biological Parameters } \\
\hline 43 & Escherichia coli & $\begin{array}{l}\text { Present or Absent per } \\
\text { Gram }\end{array}$ & Absent \\
\hline 44 & Salmonella & $\begin{array}{l}\begin{array}{l}\text { Present or Absent / } 25 \\
\text { grams }\end{array}\end{array}$ & Absent \\
\hline
\end{tabular}

(BDL indicates Below Detectable Limit) 
Table.4 Details of heavy metals / amino acids present in the sample moringa leaf powder

\begin{tabular}{|c|c|c|c|}
\hline SI. No & Particulars of Nutrients / Minerals & Units & Test Results \\
\hline \multicolumn{4}{|c|}{ Heavy Metals } \\
\hline 01 & Lead as $\mathrm{Pb}$ & $\mathrm{Mg} / \mathrm{Kg}$ & $\mathrm{BDL}[\mathrm{DL}-0.25]$ \\
\hline 02 & Cadmium as $\mathrm{Cd}$ & $\mathrm{Mg} / \mathrm{Kg}$ & $\mathrm{BDL}[\mathrm{DL}-0.10]$ \\
\hline $\mathbf{0 3}$ & Arsenic as As & $\mathrm{Mg} / \mathrm{Kg}$ & $\mathrm{BDL}[\mathrm{DL}-0.02]$ \\
\hline 04 & Mercury as $\mathrm{Hg}$ & $\mathrm{Mg} / \mathrm{Kg}$ & $\mathrm{BDL}[\mathrm{DL}-0.02]$ \\
\hline \multicolumn{4}{|c|}{ Amino Acids } \\
\hline 05 & DL-2-Amino-N-Butyric Acid & $\mathrm{Mg} / 100$ Grams & 308.40 \\
\hline 06 & L- Alamine & $\mathrm{Mg} / 100 \mathrm{Grams}$ & 238.70 \\
\hline 07 & L- Argenine & $\mathrm{Mg} / 100$ Grams & 1683.60 \\
\hline 08 & DL- Aspartic Acid & $\mathrm{Mg} / 100$ Grams & 108.60 \\
\hline 09 & L- Cycsteine & $\mathrm{Mg} / 100 \mathrm{Grams}$ & 60.20 \\
\hline 10 & L - Cystine & $\mathrm{Mg} / 100$ Grams & 30.40 \\
\hline 11 & DL - Alaline & $\mathrm{Mg} / 100$ Grams & 201.00 \\
\hline 12 & L-Glutamic Acid & $\mathrm{Mg} / 100$ Grams & 221.20 \\
\hline 13 & Glycin & $\mathrm{Mg} / 100$ Grams & 10.40 \\
\hline 14 & L - Histidine & $\mathrm{Mg} / 100 \mathrm{Grams}$ & 285.40 \\
\hline 15 & L - Hydroxy Proline & $\mathrm{Mg} / 100$ Grams & 30.20 \\
\hline 16 & DL - Iso-leucine & $\mathrm{Mg} / 100$ Grams & 97.00 \\
\hline 17 & DL - Nor - Leucine & $\mathrm{Mg} / 100 \mathrm{Grams}$ & 374.30 \\
\hline 18 & L - Leucine & $\mathrm{Mg} / 100$ Grams & 10.40 \\
\hline 19 & L - Lysine & Mg / 100 Grams & 00.60 \\
\hline 20 & DL - Methionine & $\mathrm{Mg} / 100$ Grams & 00.30 \\
\hline 21 & L - Ornithine & $\mathrm{Mg} / 100 \mathrm{Grams}$ & 00.10 \\
\hline 22 & DL - Phenylalanine & $\mathrm{Mg} / 100$ Grams & 453.00 \\
\hline 23 & L - Proline & $\mathrm{Mg} / 100$ Grams & 00.30 \\
\hline 24 & DL - Serine & $\mathrm{Mg} / 100$ Grams & 331.10 \\
\hline 25 & DL - Threonine & $\mathrm{Mg} / 100$ Grams & 00.10 \\
\hline 26 & DL - Tryptophane & Mg / 100 Grams & 95.10 \\
\hline 27 & L - Tyrosine & $\mathrm{Mg} / 100$ Grams & 203.00 \\
\hline 28 & DL - Valine & $\mathrm{Mg} / 100$ Grams & 559.00 \\
\hline
\end{tabular}

Table.5 Details of chemical analysis of moringa seed oil

\begin{tabular}{|c|l|c|c|}
\hline Sl. No & \multicolumn{1}{|c|}{ Test Parameters } & Unit & Test Results \\
\hline $\mathbf{0 1}$ & Moisture Content & Per Cent & 00.11 \\
\hline $\mathbf{0 2}$ & Melting Point & ${ }^{\circ} \mathrm{C}$ & 08.10 \\
\hline $\mathbf{0 3}$ & Iodine Value & -- & 67.21 \\
\hline $\mathbf{0 4}$ & Saponification Value & -- & 184.89 \\
\hline $\mathbf{0 5}$ & Peroxide Value & Milli Equi / Kg & 00.61 \\
\hline $\mathbf{0 6}$ & Density @ 20 Degree Celsius & $\mathrm{G} / \mathrm{ml}$ & 00.8956 \\
\hline $\mathbf{0 7}$ & Viscosity using U-Tube & $\mathrm{cSt}$ & 91.47 \\
\hline & Viscometer C & & 01.78 \\
\hline $\mathbf{0 8}$ & Acidity as Oleic Acid & Per Cent & 04.70 \\
\hline $\mathbf{0 9}$ & Phosphorous Content & $\mathrm{Mg} / \mathrm{Kg}$ & \\
\hline
\end{tabular}


Table.6 Fatty acid profile of moringa seed oil

\begin{tabular}{|c|l|c|c|}
\hline Sl. No & \multicolumn{1}{|c|}{ Parameters } & Unit & Test Results in Per Cent \\
\hline $\mathbf{0 1}$ & Palmitic Acid & C 16:0 & 06.50 \\
\hline $\mathbf{0 2}$ & Palmitoleic Acid & C 16:1 & 01.20 \\
\hline $\mathbf{0 3}$ & Stearic Acid & C 18:0 & 05.99 \\
\hline $\mathbf{0 4}$ & Oleic Acid & C 18:1 & 68.36 \\
\hline $\mathbf{0 5}$ & Linoleic Acid & C 18:2 & 01.36 \\
\hline $\mathbf{0 6}$ & Arachidic Acid & C 20:0 & 03.66 \\
\hline $\mathbf{0 7}$ & Gadoleic Acid & C 20:1 & 02.10 \\
\hline $\mathbf{0 8}$ & Behenic Acid & C 22:0 & 06.00 \\
\hline
\end{tabular}

Table.7 Details of heavy metal contents in moringa seed oil

\begin{tabular}{|c|l|c|c|c|}
\hline Sl. No & \multicolumn{1}{|c|}{$\begin{array}{c}\text { Name of the } \\
\text { Heavy Metals }\end{array}$} & Unit & Results & $\begin{array}{c}\text { Limit of } \\
\text { Quantification }\end{array}$ \\
\hline $\mathbf{0 1}$ & Copper as $\mathrm{Cu}$ & $\mathrm{Mg} / \mathrm{kg}$ & Not Detected & 00.05 \\
\hline $\mathbf{0 2}$ & Iron as $\mathrm{Fe}$ & $\mathrm{Mg} / \mathrm{kg}$ & Not Detected & 00.05 \\
\hline
\end{tabular}

Table.8 Details of product certifications obtained to ensure quality output of moringa

\begin{tabular}{|c|l|l|l|}
\hline Sl. No & \multicolumn{1}{|c|}{ Details of Certification } & \multicolumn{1}{|c|}{$\begin{array}{c}\text { Agency Responsible for Issuing } \\
\text { Certification }\end{array}$} & \multicolumn{1}{|c|}{ Period } \\
\hline $\mathbf{0 1}$ & $\begin{array}{l}\text { Good Manufacturing } \\
\text { Practices (GMP) }\end{array}$ & $\begin{array}{l}\text { International Accreditation Bureau, } \\
\text { London, UK }\end{array}$ & $\begin{array}{l}24.09 .2016 \text { to } \\
23.09 .2019\end{array}$ \\
\hline $\mathbf{0 2}$ & HALAL Certification & $\begin{array}{l}\text { Quality Council of International } \\
\text { Certification, UK }\end{array}$ & $\begin{array}{l}24.09 .2016 \text { to } \\
23.09 .2019\end{array}$ \\
\hline $\mathbf{0 3}$ & $\begin{array}{l}\text { Hazard Analysis and } \\
\text { Critical Control Points } \\
\text { (HACCP) }\end{array}$ & $\begin{array}{l}\text { Ingrain Standard Assessment LLP, } \\
\text { Madurai }\end{array}$ & $\begin{array}{l}18.06 .2018 \text { to } \\
17.06 .2021\end{array}$ \\
\hline $\mathbf{0 4}$ & ISO 9001:2015 & $\begin{array}{l}\text { Accreditation Service for Certifying } \\
\text { Bodies (Europe) Limited, UK }\end{array}$ & $\begin{array}{l}19.06 .2018 \text { to } \\
18.06 .2021\end{array}$ \\
\hline
\end{tabular}


Fig.1 Flow chart showing the method of value addition of moringa produce

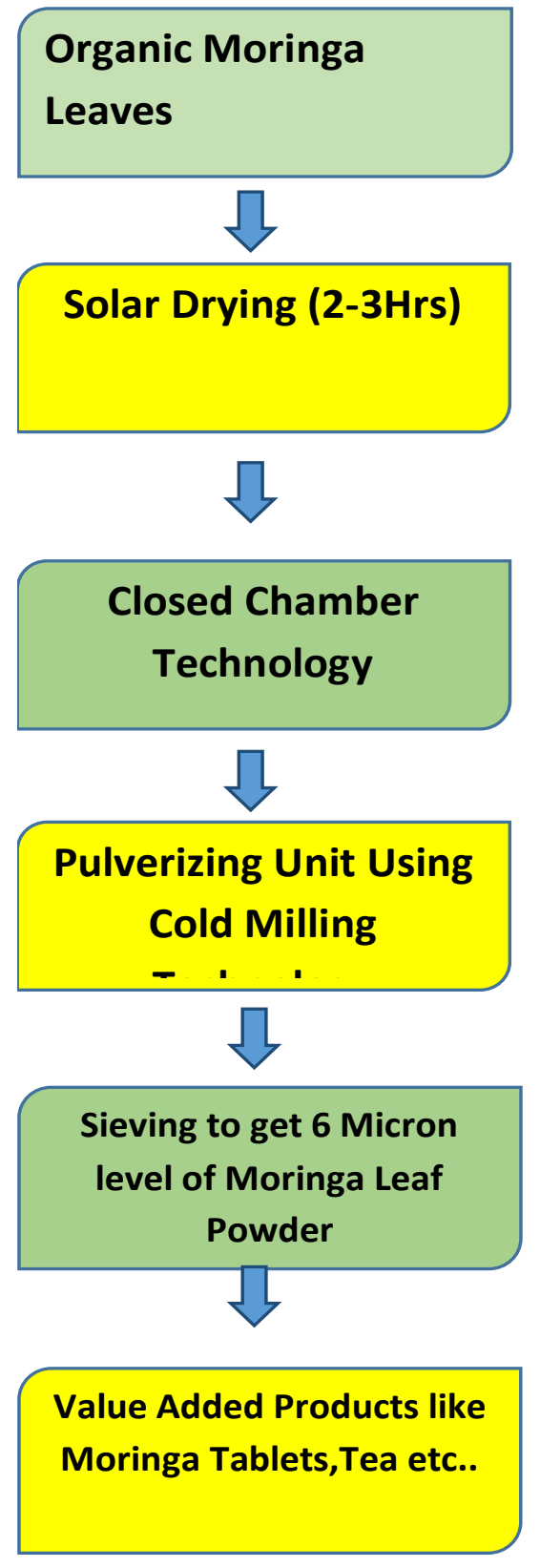

According to Sivaprakasam et.al. (2017) Gas Chromatography Mass Spectrometry analysis confirmed the presence of 17 bioactive constituents that may be the principal factors in the significant antibacterial, antioxidant and would healing activity in Moringa. Different concentrations of the Moringa leaves fraction@of 12.50, 25, $50 \mu \mathrm{g} / \mathrm{mL}$
Wild Collection of

Moringa Pods
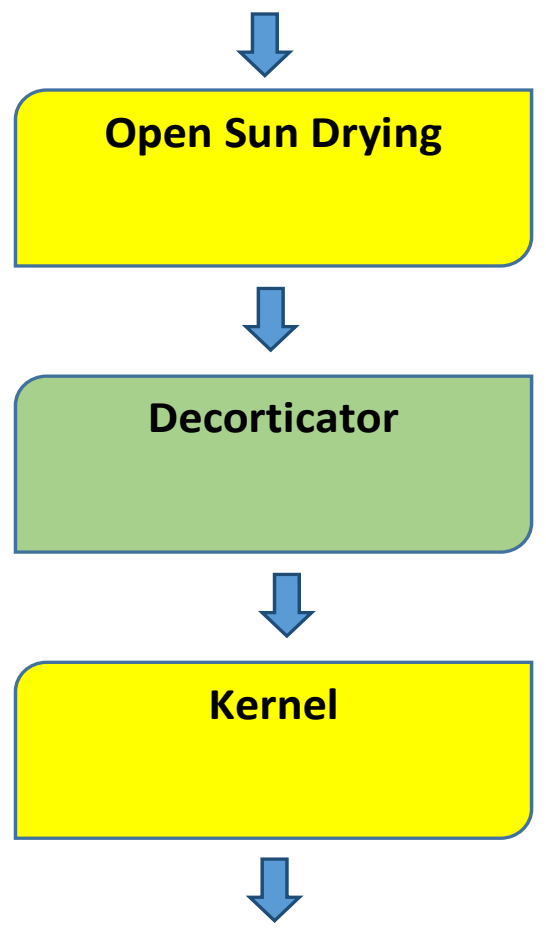

Cold Milling

Technology



Moringa Seed Oil

were applied for 24 hours after wound scratching. The wound coverage was significantly increased for Human Dermal Fibroblast (HDF-D) cells at all concentrations compared with the control group. Although the control group cells slightly closed the scratched area, Moringa leaves Ethyl Acetate fraction treated HDF-D cells were found to 
migrate faster following a 24 hour incubation period.

\section{Summary}

Moringa has been well understood by the humanity and their effort to tap the benefits of Moringa is a continuous process. In that race, Miracletree Life Sciences Private Limited, Madurai has also joined hands and started promoting value added products of Moringa in an organic way. In evidence of Organic production, the company has obtained HALAL certification, food safety certificates like HACCP and Good Manufacturing Practices certificates were obtained and the product innovation race is popular. Hope in the race of manufacturing and supply of quality produce to the humanity, the company will have a big share and lead the global supply in a big way in near future.

\section{References}

Amabye, T.G. (2015) "Chemical Composition and Nutritional Value of Moringa oleifera Available in the Market of Makelle", Journal of Food and
Nutrition Sciences, 3 (5): 187-190

NAWaL Analytical Laboratories (2018), Test Results of Moringa (NAWaL Analytical Laboratories: Madurai)

Neogen (2017), Test Reports of Moringa Produce (Neogen Food and Animal Security (India) Private Limited: Cochin)

Saravanakumaran (2016), Miracle Tree Brochure (Miracle Tree Life Sciences Private Limited: Madurai)

Saravanakumaran (2018), Miracletree Product Brochure (Miracle Tree Life Sciences Private Limited: Madurai)

Sivapragasam, G., M. Katyakyini, Mazni Abu Zarin, Tan Woan Sean, S. Suresh Kumar, A.M. Murugan, F. Sharida and P. Arulselvan (2017) " Chemical Composition of Moringa oleifera Ethyl Acetate Fraction and its Biological Activity in Diabetic Human Dermal Fibroblasts", Pharmacognosy Magazine, 13 (3): 462-469.

\section{Web Reference}

https://www.researchgate.net/.../288417816_F atty_acids_in_Moringa_oleifera_oil

\section{How to cite this article:}

Saravanakumaran, R., C. Sekhar and Murugesan, S. 2019. Value Addition, Nutritional Parameters and Quality Certifications in Exportable Organic Moringa Produce. Int.J.Curr.Microbiol.App.Sci. 8(01): 813-828. doi: https://doi.org/10.20546/ijcmas.2019.801.089 